\title{
Lactobacillus rhamnosus GG and Biochemical Agents Enrich the Shelf Life of Fresh-Cut Bell Pepper (Capsicum annuum L. var. grossum (L.) Sendt)
}

\author{
Kandasamy Saravanakumar ${ }^{1}{ }^{1}$, Anbazhagan Sathiyaseelan ${ }^{1}$, \\ Arokia Vijaya Anand Mariadoss ${ }^{1}{ }^{\circledR}$, Ramachandran Chelliah ${ }^{2}$, Xiaowen $\mathrm{Hu}^{1}{ }^{1}$, \\ Deog Hwan $\mathrm{Oh}^{2}$ and Myeong-Hyeon Wang ${ }^{1, *}$ \\ 1 Department of Medical Biotechnology, College of Biomedical Sciences, Kangwon National University, \\ Chuncheon 24341, Korea; saravana732@kangwon.ac.kr or saravana732@gmail.com (K.S.); \\ sathiyaseelan.bio@gmail.com (A.S.); mavijaibt@gmail.com (A.V.A.M.); huxiaowen9520@gmail.com (X.H.) \\ 2 Department of Food Science and Biotechnology College of Biotechnology and Bioscience, \\ Kangwon National University, Chuncheon 24341, Korea; ramachandran865@gmail.com (R.C.); \\ deoghwa@kangwon.ac.kr (D.H.O.) \\ * Correspondence: mhwang@kangwon.ac.kr
}

Received: 28 July 2020; Accepted: 2 September 2020; Published: 7 September 2020

\begin{abstract}
This work analyzed the individual and combined effects of biochemical additives and probiotic strain Lactobacillus rhamnosus GG on red and yellow fresh-cut bell pepper (R- and Y-FCBP, respectively) stored at two different temperatures $\left(4^{\circ} \mathrm{C}\right.$ and $\left.15^{\circ} \mathrm{C}\right)$ for 15 days. The results revealed that the combined application of biochemical additives and L. rhamnosus GG inhibited the colonization of total bacterial counts $(25.10 \%)$, total Salmonella counts $(38.32 \%)$, total Listeria counts $(23.75 \%)$, and total fungal counts $(61.90 \%)$ in FCBP. Total bacterial colonization was found to be higher in R-FCBP $\left(1188.09 \pm 9.25 \mathrm{CFU} \mathrm{g}^{-1}\right)$ than Y-FCBP $\left(863.96 \pm 7.21 \mathrm{CFU} \mathrm{g}^{-1}\right)$. The storage at $4{ }^{\circ} \mathrm{C}$ was prevented $35.38 \%$ of microbial colonization in FCBP. Importantly, the L. rhamnosus GG count remained for up to 12 days. Moreover, the combined inoculation of the biochemical additives and L. rhamnosus GG treatments (T3) maintained the quality of R- and Y-FCBP for up to 12 days at $4{ }^{\circ} \mathrm{C}$ without any loss of antioxidant properties. This work reports the successful utilization of L. rhamnosus GG as a preservative agent for maintaining the quality of FCBP by preventing microbial colonization.
\end{abstract}

Keywords: probiotics; Lactobacillus rhamnosus; bell pepper; food quality; foodborne

\section{Introduction}

Bell pepper (in other words, paprika or sweet pepper) is one of the leading greenhouse products in South Korea. Annually, about 20,000 tons of bell pepper is produced and exported to various countries. In particular, $60 \%$ of Korean bell pepper are commercialized in Japanese markets [1,2]. However, the transportation of bell pepper in the form of fresh-cut products (FCP) is more voluminous in terms of kilograms than that of whole bell pepper, using the same container, and this can increase the economic value and reduce the transportation charges. Moreover, people are very interested in consuming the fresh-cut form of the sweet pepper without loss of nutritional value. However, there is a high risk of food pathogen contamination during the preparation of fresh-cut bell pepper (FCBP) by cutting, peeling, and slicing methods, which lead to tissue damage, the release of nutrients, and attraction of microbial contamination, resulting in the loss of flavor and texture, as well as browning [3]. Moreover, the consumption of improperly processed FCP may lead the severe illness to human. A list of food pathogen (Salmonella, Escherichia coli, or Listeria monocytogenes)-based outbreaks have been reported in past decades, such as the infection of listeriosis by L. monocytogenes due to consumption of various 
fresh fruits and vegetables [4] in 1994, E. coli (O11:H7) infection in the United States [5], and Shiga toxin-producing E. coli O104 causing hemolytic-uremic syndrome in Europe in 2014 [6]. Moreover, L. monocytogenes are associated with $20-30 \%$ of the fatalities, which is higher than that of other foodborne pathogens [7], and its contaminations in raw foods and lettuce have been reported from the China and Korea, respectively, which caused the listeriosis [8,9]. The E. coli O157: H7 and Listeria spp are known to significantly contaminate several fresh products of lettuce, cucumber, carrot, soybean sprouts, packed fresh-cut salad, apples, melon, and peaches [9-14]. The Korea Food and Drug administration (KFDA) has provided prevention measures to control the foodborne pathogenic (Salmonella sp., Listeria sp., E. coli, and fungi, etc.) infections [15]. Also, another report has consolidated the global foodborne outbakes related to the FCP and key prevention measures [16].

To inhibit microbial contamination in FCP, several processing methods are currently applied, including low-temperature refrigeration, minimal processing, sanitization solution washing (hydrogen peroxide, chlorine, ozone, and organic acids), anti-browning agents, chemical dipping in edible coating, and antibacterial essential oil treatments [17-20]. However, the effect of these approaches are different based on the response of the FCP; therefore, it is important to optimize appropriate conditions to expand the shelf life of FCP based on the fruits and vegetables [19]. Therefore, a novel invention is needed for hygienic food processing and storage to avoid food safety-related issues and maintain the good quality of FCP for better transportation and direct commercialization [3]. However, among various sanitizer-based treatments, the biopreservation techniques using living probiotic lactic acid bacteria (LAB) are promising as far as having an inhibitory effect on foodborne pathogens through the production of various metabolites, such as lactic acids and peptides [21,22]. Also, probiotics are advantageous to the host by improving intestinal microbiota and immunity [22]. Some of the probiotics are known to be utilized as preservative agents for FCP, and particularly L. rhamnosus GG is reportedly expanding the shelf life of FCP, such as pineapple, apple, pears, and melon [23-26]. However, there is no work reporting the utilization of L. rhamnosus GG to expand the shelf life of FCBP. Therefore, the present work tested the effect of L. rhamnosus GG combined with biochemical additives on the shelf life of FCBP.

\section{Materials and Methods}

\subsection{Bell Pepper and Microbes}

Two different colors (red and yellow) of fresh and healthy bell pepper used in this study were purchased from local farmers in Chuncheon, Republic of Korea, and transported to the laboratory. The bacterial strains used were L. monocytogenes (ATCC 19118), S. Typhimurium (ATCC14028), and L. rhamnosus GG (ATCC 53103) from the American type of the culture collection located in University Blvd, Manassas, VA, United States. The culture media used were tryptic soy broth (TSB) and tryptic soy agar (TSA); xylose-lysine-desoxycholate agar (XLD); Polymyxin acriflavine lithium chloride ceftazidime aesculin mannitol (PALCAM) agar; and de Man, Rogosa, and Sharpe agar and broth (MRSA and MRSB, respectively) from Oxoid (Basingstoke, Hampshire, UK). Sterile peptone water was purchased from BactoTM, Difco, MD, United States. Phosphate-buffered saline (PBS; Corning Mediatech, Inc., Corning, NY, USA), sodium benzoate, ascorbic acid, and DL- $\alpha$-tocopherol acetate were obtained from Sigma Aldrich, the Republic of Korea.

\subsection{Preparation of Biochemical Additive Solution and Bacterial Inoculum}

The biochemical additive solution was prepared by dissolving the $20 \mathrm{~g} \mathrm{~L}^{-1}$ of ascorbic acid, $200 \mathrm{mg}$. $\mathrm{L}^{-1}$ of sodium benzoate, and $2 \mathrm{~g} \mathrm{~L}^{-1}$ of DL- $\alpha$-tocopherol acetate in distilled water. The bacterial strains, such as L. monocytogenes and S. Typhimurium, were retrieved from $20 \%$ glycerol stock by inoculating on TSA media by a simple streak plate method, and were allowed to grow in an incubator at $37^{\circ} \mathrm{C}$ for $24 \mathrm{~h}$. The single colonies of bacteria were transferred to $10 \mathrm{~mL}$ of TSB and incubated for $15-18 \mathrm{~h}$ at $37^{\circ} \mathrm{C}$. Then the cells were collected by centrifugation at $3000 \mathrm{rpm}$ for $10 \mathrm{~min}$. The harvested 
cells were resuspended in sterile peptone water and the concentration of the cells was adjusted to $10^{5} \mathrm{CFU} \mathrm{mL} \mathrm{mL}^{-1}$ for L. monocytogenes and S. Typhimurium, and then mixed in $10 \mathrm{~mL}$ of peptone water to obtain the foodborne cocktails (FBC). The probiotic strain L. rhamnosus GG was retrieved from the stock, according to instructions provided from ATCC, and cultured in MRSA. The cells were grown in MRSB until the late stationary phase in an incubator at $37^{\circ} \mathrm{C}$. Afterward, the cells were collected by centrifugation at $9000 \mathrm{rpm}$ for $10 \mathrm{~min}$ at $8{ }^{\circ} \mathrm{C}$, and the concentration of the cells was adjusted to $10^{8} \mathrm{CFU} \mathrm{mL} \mathrm{mL}^{-1}$ for L. rhamnosus GG. The final concentration of each cells were checked by culturing appropriate dilution XLD for Salmonella, Palcam agar for Listeria, and MRSA for L. rhamnosus GG.

\subsection{Preparation of the FCBP and Treatments}

To apply various treatments, the yellow and red colors of bell pepper were cut into fragments sized at $4 \times 3 \mathrm{~cm}$ using a sterilized knife, and air-dried and divided into a total of 10 groups for each color of FCBP. This was done in triplicates, in which five groups were at $4{ }^{\circ} \mathrm{C}$ and five groups were at $15^{\circ} \mathrm{C}$ preservation. Each group of FCBP was treated $(1: 3 w / v)$ for $2 \mathrm{~min}$ at $120 \mathrm{rpm}$ in any one of the following treatments: $\mathrm{T} 0=$ untreated, $\mathrm{T} 1=$ biochemical additives solution-treated, $\mathrm{T} 2=$ biochemical additive solution with FBC, T3 = biochemical additive solution with probiotic strain $L$. rhamnosus GG $\left(10^{8} \mathrm{CFU} \mathrm{mL}{ }^{-1}\right), \mathrm{T} 4=$ biochemical additive solution with FBC and L. rhamnosus $\mathrm{GG}\left(10^{8} \mathrm{CFU} \mathrm{mL}^{-1}\right)$. After the treatments, FCBP samples were aseptically dried by laying on sterile blotting paper in a clean cabinet to remove the water vapors. Then the samples were packed in a sterile polypropylene container with a size of $9.5 \times 7.5 \mathrm{~cm}$ and stored in two different temperatures $\left(4{ }^{\circ} \mathrm{C}\right.$ and $\left.15^{\circ} \mathrm{C}\right)$ and $70 \%$ relative humidity. The microbial quality, nutritional, color, and sensory properties of FCBP were frequently measured by collecting the aliquots of samples at three-day intervals from 0 to 15 days. The detailed experimental design was presented in Scheme 1. The concentration of the sodium benzoate in the FCBP was determined by using the methods described earlier [27].

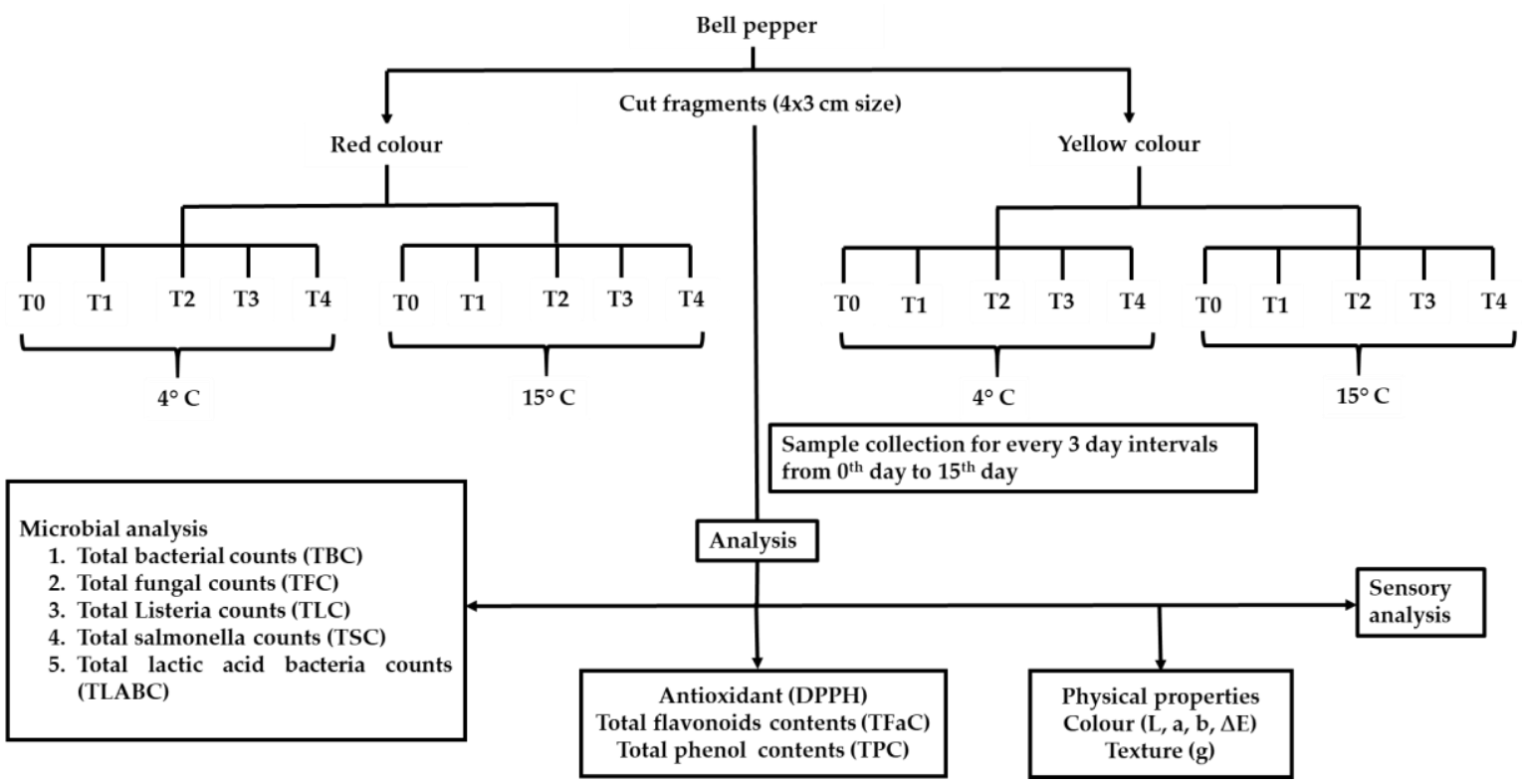

Scheme 1. Schematic representation of the experimental design.

\subsection{Enumeration of Microbial Colonization}

To enumerate the microbial colonization, $5 \mathrm{~g}$ of the FCBP were dissolved in $10 \mathrm{~mL}$ of the sterile distilled $\mathrm{H}_{2} \mathrm{O}$ and serially diluted up to $10^{-7}$. The $50 \mu \mathrm{L}$ of $10^{-5}$ dilution was spread on the nutrient agar (NA) for total bacterial counts, XLD for total salmonella, PALCAM for total Listeria, MRSA for total $\mathrm{LAB}$, and potato dextrose agar (PDA) for total fungal enumeration $[26,28]$. The plates with MRSA, XLD, PALCAM agar, and NA were incubated at $37^{\circ} \mathrm{C}$ for $24 \mathrm{~h}$, while the PDA plates were incubated 
at $28{ }^{\circ} \mathrm{C}$ for four days. After the incubation period, the microbial counts were enumerated using the standard methods, as described [28]. The colonies corresponding to the Listeria sp. were confirmed based on the colony morphologies, as indicated with a grey-green color with a black center and a black halo. Similarly, the salmonella sp. were identified based on the red colonies with black centers for some colonies.

\subsection{DPPH Scavenging, Total Phenol, Flavonoids, Color, Texture, and Sensory Properties}

A total of $70 \mathrm{~g}$ of the FCBP was collected from each treatment every three days $(0,3,6,9,12,15$ days) and subjected to water extraction. This water extract was used for 2,2-diphenyl-1-picrylhydrazyl (DPPH) scavenging, total phenol, and total flavonoids assays. The DPPH assay was performed according to the methods reported earlier [29], and the Folin-Ciocalteu assay was adapted to measure the total phenol content (TPC) [30]. The hardness (g) was measured by texture analyzer (Brookfield, AMETEK $\mathrm{GmbH}$, Lorch, Germany). The color changes, including $L$ (lightness), $a$ (redness), and $b$ (yellowness) were observed by colorimeter (CR300; Minolta Co., Osaka Japan). Sensory properties of the FCBP were monitored by nine trained experts, and the sensory quality was scaled according to the method described earlier, with minor modifications [31]. The sensory quality was scored from 1 to 10, with 1-2 meaning extremely poor, 3-4 as poor (limit edibility), 5-6 as acceptable (limit of marketing), $7-8$ as looks fresh and good, and $9-10$ as excellent quality.

\section{Results and Discussion}

\subsection{Microbial Changes}

There is so far no report on the utilization of probiotic bacteria in combination with a biochemical additive solution to improve the quality of FCBP through inhibiting foodborne microbes. Therefore, this work evaluated the individual and combined effects of biochemical additives and L. rhamnosus GG on the quality and shelf life of FCBP. The application of probiotics in FCP was found to be advantageous in inhibiting foodborne pathogens. The descriptive statistical analysis of the microbial colonization in R- and Y-FCBP concerning the various time intervals, treatments, and storage temperatures is presented as supplementary tables (SI; Tables S1 and S2). In the present work, microbial count in FCBP was significantly different between the treatments, color of FCBP, temperature, and intervals $(p<0.05$; Table 1). The total bacteria count (TBC) ranged from $412.2 \pm 2.89$ to $1959.30 \pm 6.14$ CFU $\mathrm{g}^{-1}$ for the treatments, and it was found to be higher in T0 and lower in T3. In terms of the color of FCBP, the maximum was found in R-FCBP $\left(1188.09 \pm 9.25 \mathrm{CFU} \mathrm{g}^{-1}\right)$ and the minimum in Y-FCBP $\left(863.96 \pm 7.21 \mathrm{CFU} \mathrm{g}^{-1}\right)$. In the case of preservation temperatures, $\mathrm{TBC}$ was observed more at $15^{\circ} \mathrm{C}$ than at $4{ }^{\circ} \mathrm{C}$. Furthermore, the colonization of TBC remarkably increased with increasing days of preservation. Thus, L. rhamnosus GG was highly efficient in inhibiting bacterial colonization in FCBP. The consumption of probiotic-treated fruits have been reported to reduce the incidence of cancer and cardiovascular diseases [32-34]. Lactic acid bacteria are known to potentially prevent bacterial colonization, due to their production of health-promoting metabolites [35].

The total Salmonella count (TSC) was observed to be higher in T2 $\left(640.43 \pm 2.34 \mathrm{CFU} \mathrm{g}^{-1}\right)$ and lower in T1 and T3. TSC colonization was recorded more in R-FCBP $\left(225.56 \pm 4.25 \mathrm{CFU} \mathrm{g}^{-1}\right)$ than in Y-FCBP $\left(129.52 \pm 2.15 \mathrm{CFU} \mathrm{g}^{-1}\right)$. It was found higher with the preservation temperature of $15^{\circ} \mathrm{C}$ $\left(239.16 \pm 8.14 \mathrm{CFU} \mathrm{g}^{-1}\right)$ and lower in $4{ }^{\circ} \mathrm{C}\left(115.98 \pm 6.15 \mathrm{CFU} \mathrm{g}{ }^{-1}\right)$. The TSC was found higher in the 0 day interval, but it decreased by days 3 and 6, followed by an increase in the 15 day interval. The combined application of biochemical additives and L. rhamnosus GG controlled the colonization of Salmonella in FCBP. TLC increased in T2 $\left(431.36 \pm 6.11 \mathrm{CFU} \mathrm{g}{ }^{-1}\right)$ and decreased in T1 and T3. The population of TLC was found to be greater in R-FCBP $\left(149.69 \pm 1.96 \mathrm{CFU} \mathrm{g}^{-1}\right)$ and lower in Y-FCBP $\left(64.47 \pm 2.89 \mathrm{CFU} \mathrm{g}^{-1}\right)$. It increased at the preservation temperature of $15^{\circ} \mathrm{C}\left(125.04 \pm 1.69 \mathrm{CFU} \mathrm{g}^{-1}\right)$ and decreased at $4{ }^{\circ} \mathrm{C}\left(89.24 \pm 2.13 \mathrm{CFU} \mathrm{g}^{-1}\right)$. The co-inoculation of L. rhamnosus GG significantly inhibited the growth behavior of Listeria more than that of Salmonella in FCBP. The present work observed a 
negative correlation between TSC and total lactic acid bateria count (TLABC) (Table 1). Similarly, earlier work has reported that L. rhamnosus GG co-inoculation successfully controls the growth of L. monocytogenes better than that of Salmonella in apple wedges [22]. Several studies have reported the broad spectrum of antagonistic activity of L. rhamnosus GG against foodborne pathogens [36].

Table 1. Determination of microbial population changes in red $(\mathrm{R})$ and yellow $(\mathrm{Y})$ fresh-cut bell pepper (FCBP) treated or untreated with L. rhamnosus GG and biochemical agents at different time intervals (days) and preserved in two different temperatures $\left(4\right.$ and $\left.15{ }^{\circ} \mathrm{C}\right)$. The results presented the estimated marginal means \pm standard error $(\mathrm{SE}) .{ }^{*}$ Significant $(p<0.01)$; NS: not significant, TBC: total bacteria count, TSC: total Salmonella count, TLC: total Listeria count, TFC: total fungal count, TLABC: total lactic acid bacterial count, $F=$ variation between sample means/variation within the samples.

\begin{tabular}{|c|c|c|c|c|c|}
\hline \multirow{2}{*}{ Sources } & \multicolumn{5}{|c|}{ Microbial Counts (CFU g ${ }^{-1}$ ) } \\
\hline & ТВC & TSC & TLC & TFC & TLABC \\
\hline \multicolumn{6}{|l|}{ Treatments } \\
\hline T0 & $1959.30 \pm 6.14$ & $1.83 \pm 0.23$ & $1.57 \pm 0.05$ & $1000.87 \pm 4.55$ & 0 \\
\hline $\mathrm{T} 1$ & $911.6 \pm 2.56$ & 0 & 0 & $753.61 \pm 6.23$ & 0 \\
\hline $\mathrm{T} 2$ & $1031.21 \pm 8.74$ & $640.43 \pm 2.34$ & $431.36 \pm 6.11$ & $836.28 \pm 2.56$ & 0 \\
\hline T3 & $412.2 \pm 2.89$ & 0 & 0 & $115.57 \pm 5.79$ & $86.30 \pm 3.55$ \\
\hline $\mathrm{T} 4$ & $491.87 \pm 7.25$ & $245.43 \pm 5.26$ & $102.48 \pm 2.13$ & $619.59 \pm 6.13$ & $83.14 \pm 0.84$ \\
\hline \multicolumn{6}{|l|}{ Colors } \\
\hline R-FCBP & $1188.09 \pm 9.25$ & $225.56 \pm 4.25$ & $149.69 \pm 1.96$ & $932.94 \pm 3.93$ & $33.79 \pm 2.84$ \\
\hline Y-FCBP & $863.96 \pm 7.21$ & $129.52 \pm 2.15$ & $64.47 \pm 2.89$ & $397.55 \pm 3.71$ & $33.98 \pm 3.08$ \\
\hline \multicolumn{6}{|l|}{ Temperature $\left({ }^{\circ} \mathrm{C}\right)$} \\
\hline 4 & $585.05 \pm 8.25$ & $115.98 \pm 6.15$ & $89.24 \pm 2.13$ & $199.06 \pm 9.29$ & $35.19 \pm 1.85$ \\
\hline 15 & $1367.2 \pm 4.25$ & $239.16 \pm 8.14$ & $125.04 \pm 1.69$ & $1131.43 \pm 2.30$ & $32.58 \pm 4.79$ \\
\hline \multicolumn{6}{|l|}{ Intervals (Days) } \\
\hline 0 & $195.30 \pm 4.26$ & $210.83 \pm 2.64$ & $164.14 \pm 3.73$ & $24.38 \pm 2.21$ & $48.94 \pm 1.97$ \\
\hline 3 & $672.58 \pm 2.54$ & $99.47 \pm 6.12$ & $110.58 \pm 2.39$ & $457.77 \pm 2.14$ & $32.29 \pm 1.50$ \\
\hline 6 & $895.10 \pm 4.27$ & $125.44 \pm 4.52$ & $67.19 \pm 1.62$ & $724.84 \pm 3.13$ & $32.75 \pm 3.65$ \\
\hline 9 & $1287.33 \pm 2.21$ & $234.83 \pm 53.15$ & $84.21 \pm 5.85$ & $891.25 \pm 8.00$ & $30.57 \pm 1.07$ \\
\hline 12 & $1271.81 \pm 9.25$ & $153.40 \pm 8.21$ & $97.84 \pm 1.00$ & $912.70 \pm 3.60$ & $30.20 \pm 2.51$ \\
\hline 15 & $1533.28 \pm 5.26$ & $192.67 \pm 1.62$ & $118.52 \pm 2.65$ & $980.75 \pm 1.24$ & $28.57 \pm 1.35$ \\
\hline \multicolumn{6}{|l|}{ Significance } \\
\hline Treatments & $(F=1115.24)^{* *}$ & $(F=35,445.03)^{* *}$ & $(F=23,970.39)^{* *}$ & $(F=27,561.41)^{* *}$ & $(F=18,963.46)^{* *}$ \\
\hline Colors & $(F=284.64)^{* *}$ & $(F=5157.02)^{* *}$ & $(F=6088.55)^{* *}$ & $(F=85,918.17)^{* *}$ & $(F=0.019)^{\mathrm{NS}}$ \\
\hline Temperature $\left({ }^{\circ} \mathrm{C}\right)$ & $(F=2489.02)^{* *}$ & $(F=8512.48)^{* *}$ & $(F=1054.36)^{* *}$ & $(F=244,433.7)^{* *}$ & $(F=66.97)^{* *}$ \\
\hline Intervals (days) & $(F=500.68)^{* *}$ & $(F=1138.20)^{* *}$ & $(F=666.34)^{* *}$ & $(F=17,773.40)^{* *}$ & $(F=421.33)^{* *}$ \\
\hline
\end{tabular}

The TFC population was higher in T0 $\left(1000.87 \pm 4.55 \mathrm{CFU} \mathrm{g}^{-1}\right)$ and lower in $\mathrm{T} 3\left(115.57 \pm 5.79 \mathrm{CFU} \mathrm{g}^{-1}\right)$. The population of TFC was found to be greater in R-FCBP $\left(932.94 \pm 3.93 \mathrm{CFU} \mathrm{g}^{-1}\right)$ and smaller in Y-FCBP $\left(397.55 \pm 3.71 \mathrm{CFU} \mathrm{g}^{-1}\right)$. It was also greater at the storage temperature of $15^{\circ} \mathrm{C}\left(1131.43 \pm 2.30 \mathrm{CFU} \mathrm{g}{ }^{-1}\right)$ and lower at $4^{\circ} \mathrm{C}\left(199.06 \pm 9.29 \mathrm{CFU} \mathrm{g}^{-1}\right)$, and increased with increasing time of storage. The biochemical additives and low molecular weight molecules from viable cells of L. rhamnosus GG might be involved in the inhibition of fungal colonization in FCBP. Similarly, the Lactobacilli are known to inhibit fungi in dairy products $[37,38]$. The Lactobacilli (LAB) was absent in $\mathrm{T} 0, \mathrm{~T} 1$, and $\mathrm{T} 2$, but present in $\mathrm{T} 3$ and $\mathrm{T} 4$, because LAB was not treated in T0, T1, and T2. Moreover, the L. rhamnosus GG count was remained for up to 12 days in $\mathrm{T} 3$ and $\mathrm{T} 4$ at both temperatures. The presence of the LAB significantly reduced the colonization of foodborne pathogens, such as Salmonella, Listeria, total bacteria, and total fungi. The results indicate that the biochemical additive solution combination with viable cells of $L$. rhamnosus GG treatments prevented foodborne pathogenic colonization in both red and yellow FCBP. 


\subsection{Phytochemical Changes and Antioxidant Properties}

The results of antioxidant and phytocomponents, such as total flavonoids and total phenol, in R- or Y-FCBP treated with biochemical additives and L. rhamnosus GG and stored at two temperatures for 15 days are presented in Table 2. The results reveal that antioxidants and phytocomponents were significantly different between the treatments, type of FCBP, storage temperatures, and periods $(p<0.01)$. The antioxidant activity in terms of the DPPH scavenging was found to be higher with FCBP treated with T4 (biochemical additives and L. rhamnosus GG), while it was found to be lower at T0 (biochemical additives-alone treated) and T2 (biochemical additives and FBC-treated), due to the loss of natural compounds in FCBP through colonization of the foodborne pathogens. Also, the present results evidenced the correlation between the total flavonoids and phenol in the FCBP. Similarly, a previous study has reported that the application of probiotic lactic acid bacteria does not affect the quality of fresh-cut melon, and maintains the total phenol and antioxidants [31]. The biochemical additives maintained the quality of FCBP, but the effect was not better than that of L. rhamnosus GG. Since the usage of a higher dosage of sodium benzoate as the preservative agent is dangerous to human consumption, the present study used the lower concentration of the sodium benzoate as one constituent in the biochemical additive solution. To ensure its safety in human consumption, the concentration of sodium benzoate in the FCBP treated with the biochemical additive solution were determined, and it was found to be $<0.001 \%$, which is safe for the human consumption, according to "generally recognized as safe" (GRAS) compounds by the United States Food and Drug Administration [39].

Table 2. Analysis of antioxidant and phytochemical changes in fresh-cut bell pepper (FCBP) treated or untreated with Lactobacillus rhamnosus GG and biochemical agents at different time intervals (days) and preserved in two different temperatures $\left(4\right.$ and $\left.15^{\circ} \mathrm{C}\right)$. The results presented the estimated marginal means \pm SE. ${ }^{* *}$ significant $(p<0.01)$. TFaC: total flavonoids content, and TPC: total phenolic content.

\begin{tabular}{|c|c|c|c|}
\hline Sources & DPPH Scavenging (\%) & $\mathrm{TFaC}(\mathrm{OD} 450 \mathrm{~nm})$ & TPC (OD $760 \mathrm{~nm}$ ) \\
\hline \multicolumn{4}{|l|}{ Treatments } \\
\hline T0 & $16.95 \pm 0.31$ & $0.085 \pm 0.018$ & $1.28 \pm 0.15$ \\
\hline $\mathrm{T} 1$ & $17.37 \pm 0.76$ & $0.087 \pm 0.005$ & $1.81 \pm 0.21$ \\
\hline $\mathrm{T} 2$ & $16.16 \pm 1.26$ & $0.081 \pm 0.007$ & $1.88 \pm 0.18$ \\
\hline $\mathrm{T} 3$ & $23.27 \pm 0.25$ & $0.075 \pm 0.010$ & $1.76 \pm 0.13$ \\
\hline $\mathrm{T} 4$ & $51.75 \pm 0.62$ & $0.085 \pm 0.004$ & $1.88 \pm 0.11$ \\
\hline \multicolumn{4}{|l|}{ Color of FCBP } \\
\hline R-FCBP & $24.52 \pm 2.61$ & $0.084 \pm 0.001$ & $1.75 \pm 0.17$ \\
\hline Y-FCBP & $25.69 \pm 0.76$ & $0.081 \pm 0.010$ & $1.70 \pm 0.13$ \\
\hline \multicolumn{4}{|l|}{ Temperature } \\
\hline 4 & $24.16 \pm 0.37$ & $0.081 \pm 0.004$ & $1.71 \pm 0.16$ \\
\hline 15 & $26.04 \pm 0.24$ & $0.085 \pm 0.001$ & $1.73 \pm 0.11$ \\
\hline \multicolumn{4}{|l|}{ Intervals } \\
\hline 0 & $79.95 \pm 0.13$ & $0.117 \pm 0.013$ & $1.75 \pm 0.01$ \\
\hline 3 & $17.11 \pm 1.41$ & $0.091 \pm 0.015$ & $1.86 \pm 0.08$ \\
\hline 6 & $13.87 \pm 0.76$ & $0.091 \pm 0.001$ & $1.73 \pm 0.09$ \\
\hline 9 & $15.16 \pm 0.26$ & $0.069 \pm 0.02$ & $1.71 \pm 0.16$ \\
\hline 12 & $10.94 \pm 0.77$ & $0.072 \pm 0.04$ & $1.63 \pm 0.08$ \\
\hline 15 & $13.58 \pm 1.98$ & $0.056 \pm 0.011$ & $1.66 \pm 0.02$ \\
\hline \multicolumn{4}{|l|}{ Significance } \\
\hline Treatments & $(F=16,555.60)^{* *}$ & $(F=12.15)^{* *}$ & $(F=365.10)^{* *}$ \\
\hline Color of FCBP & $(F=20.24)^{* *}$ & $(F=18.07)^{* *}$ & $(F=19.48)^{* *}$ \\
\hline Temperature & $(F=52.51)^{* *}$ & $(F=11.18)^{* *}$ & $(F=8.6)^{* *}$ \\
\hline Intervals (days) & $(F=7175.76)^{* *}$ & $(F=7.46)^{* *}$ & $(F=30.63)^{* *}$ \\
\hline
\end{tabular}




\subsection{Color and Texture Sensory Changes}

Table 3 shows physical-visual changes of FCBP treated with biochemical additives or L. rhamnosus GG and stored at two different temperatures $\left(4^{\circ} \mathrm{C}\right.$ and $\left.15{ }^{\circ} \mathrm{C}\right)$ for 15 days. In general, the analysis of physical and visual parameters, including $L$ (lightness), $a$ (redness), $b$ (yellowness), and texture is essential to understand the visual status of the fresh-cut produce. The results indicate that the color parameters, such as $L, a, b$, and texture significantly varied between the treatments, storage temperature, and days of storage $(p<0.01)$, and the color change $(\Delta E)$ showed significant variation between treatments and days of preservation, but not between storage temperatures $(p<0.05)$. After 12 days of intervals, it was not possible to analyze physical and visual parameters, due to the deterioration of the FCBP. The color parameter $L$ decreased with the increase of storage periods. The present results indicate that the storage temperature did not affect the browning of FCBP. The inoculation of pathogens' FBCs with biochemical additives did not affect the color properties of FCBP [38,40]. However, it is difficult to determine the browning of bell pepper based on the color parameters alone, because it naturally has multiple colors, including green, yellow, orange, red, etc. However, the treatment of the biochemical additives or L. rhamnosus GG in FCBP challenging with FBC did not cause the browning, due to the prevention of the foodborne pathogenic colonization (Figure 1). Also, the biochemical additive agents used are reportedly preventing the browning of fruits, including fresh-cut red apples [40-42], pomegranate [43], and fresh-cut jackfruit [44]. Moreover, the texture of the FCBP is maintained by probiotic treatments. Similarly, the application of L. rhamnosus GG does not affect the quality of apple [25], pineapples [45], and cantaloupe [31].

Table 3. Measurement of physical properties of color and textural changes in fresh-cut bell pepper (FCBP) treated or untreated with Lactobacillus rhamnosus GG and biochemical agents at different time intervals (days) and preserved in two different temperatures $\left(4\right.$ and $\left.15^{\circ} \mathrm{C}\right)$. L: lightness, $a$ : red/green value, $b$ : blue/yellow value, $\Delta E$ : color difference. The results presented the estimated marginal means \pm SE. ${ }^{* *}$ significant $(p<0.01)$; NS: not significant.

\begin{tabular}{|c|c|c|c|c|c|}
\hline Sources & $L$ & $a$ & $b$ & $\Delta E$ & Texture (g) \\
\hline \multicolumn{6}{|l|}{ Treatments } \\
\hline T0 & $22.74 \pm 0.20$ & $7.40 \pm 1.00$ & $13.76 \pm 0.55$ & $8.79 \pm 0.20$ & $597.02 \pm 5.99$ \\
\hline $\mathrm{T} 1$ & $23.36 \pm 2.04$ & $9.05 \pm 1.38$ & $12.95 \pm 1.01$ & $9.32 \pm 0.25$ & $693.54 \pm 5.49$ \\
\hline $\mathrm{T} 2$ & $170.06 \pm 2.25$ & $5.80 \pm 0.73$ & $18.18 \pm 0.51$ & $11.81 \pm 0.27$ & $540.99 \pm 11.41$ \\
\hline T3 & $27.40 \pm 1.99$ & $7.99 \pm 0.21$ & $17.56 \pm 1.99$ & $8.53 \pm 0.69$ & $739.02 \pm 2.15$ \\
\hline $\mathrm{T} 4$ & $27.96 \pm 3.04$ & $7.81 \pm 0.17$ & $18.55 \pm 2.13$ & $8.20 \pm 0.41$ & $449.33 \pm 5.88$ \\
\hline \multicolumn{6}{|l|}{ Color of FCBP } \\
\hline $\mathrm{R}$ & $28.92 \pm 1.20$ & $17.99 \pm 0.18$ & $12.93 \pm 0.63$ & $22.46 \pm 0.44$ & $659.12 \pm 4.87$ \\
\hline $\mathrm{Y}$ & $79.69 \pm 1.03$ & $2.24 \pm 0.22$ & $19.46 \pm 1.52$ & $8.23 \pm 1.77$ & $548.84 \pm 2.09$ \\
\hline \multicolumn{6}{|l|}{ Temperature } \\
\hline 4 & $88.13 \pm 2.90$ & $9.01 \pm 0.77$ & $18.44 \pm 0.55$ & $8.82 \pm 1.41$ & $842.41 \pm 9.40$ \\
\hline 15 & $20.47 \pm 1.51$ & $6.22 \pm 0.83$ & $13.96 \pm 1.73$ & $9.84 \pm 1.81$ & $365.55 \pm 3.83$ \\
\hline \multicolumn{6}{|l|}{ Intervals } \\
\hline 0 & $342.75 \pm 0.51$ & $12.46 \pm 0.03$ & $26.35 \pm 2.69$ & $5.94 \pm 0.59$ & $1018.74 \pm 8.53$ \\
\hline 3 & $240.86 \pm 0.72$ & $13.18 \pm 0.51$ & $24.95 \pm 1.53$ & $6.12 \pm 0.44$ & $1054.24 \pm 10.35$ \\
\hline 6 & $51.73 \pm 0.78$ & $7.86 \pm 0.26$ & $23.18 \pm 0.61$ & $10.93 \pm 0.14$ & $708.40 \pm 13.20$ \\
\hline 9 & $31.71 \pm 2.22$ & $8.14 \pm 0.66$ & $14.90 \pm 0.87$ & $8.59 \pm 0.65$ & $524.00 \pm 3.61$ \\
\hline 12 & $10.63 \pm 2.05$ & $3.77 \pm 0.84$ & $5.67 \pm 1.12$ & $11.79 \pm 0.87$ & $252.84 \pm 3.34$ \\
\hline \multicolumn{6}{|l|}{ Significance } \\
\hline Treatments & $(F=3.97)^{* *}$ & $(F=122.09)^{* *}$ & $(F=53.07)^{* *}$ & $(F=5.58)^{* *}$ & $(F=83.89)^{* *}$ \\
\hline Color of FCBP & $(F=3.35) * *$ & $(F=13.51)^{* *}$ & $(F=223.21)^{* *}$ & $(F=14.93)^{* *}$ & $(F=8.35)^{* *}$ \\
\hline Temperature & $(F=3.35) * *$ & $(F=619.08)^{* *}$ & $(F=120.36)^{* *}$ & $(F=0.11)^{\mathrm{NS}}$ & $(F=872.56)^{* *}$ \\
\hline Intervals (days) & $(F=4.95)^{* *}$ & $(F=1564.99)^{* *}$ & $(F=668.91)^{* *}$ & $(F=12.77)^{* *}$ & $(F=831.22)^{* *}$ \\
\hline
\end{tabular}




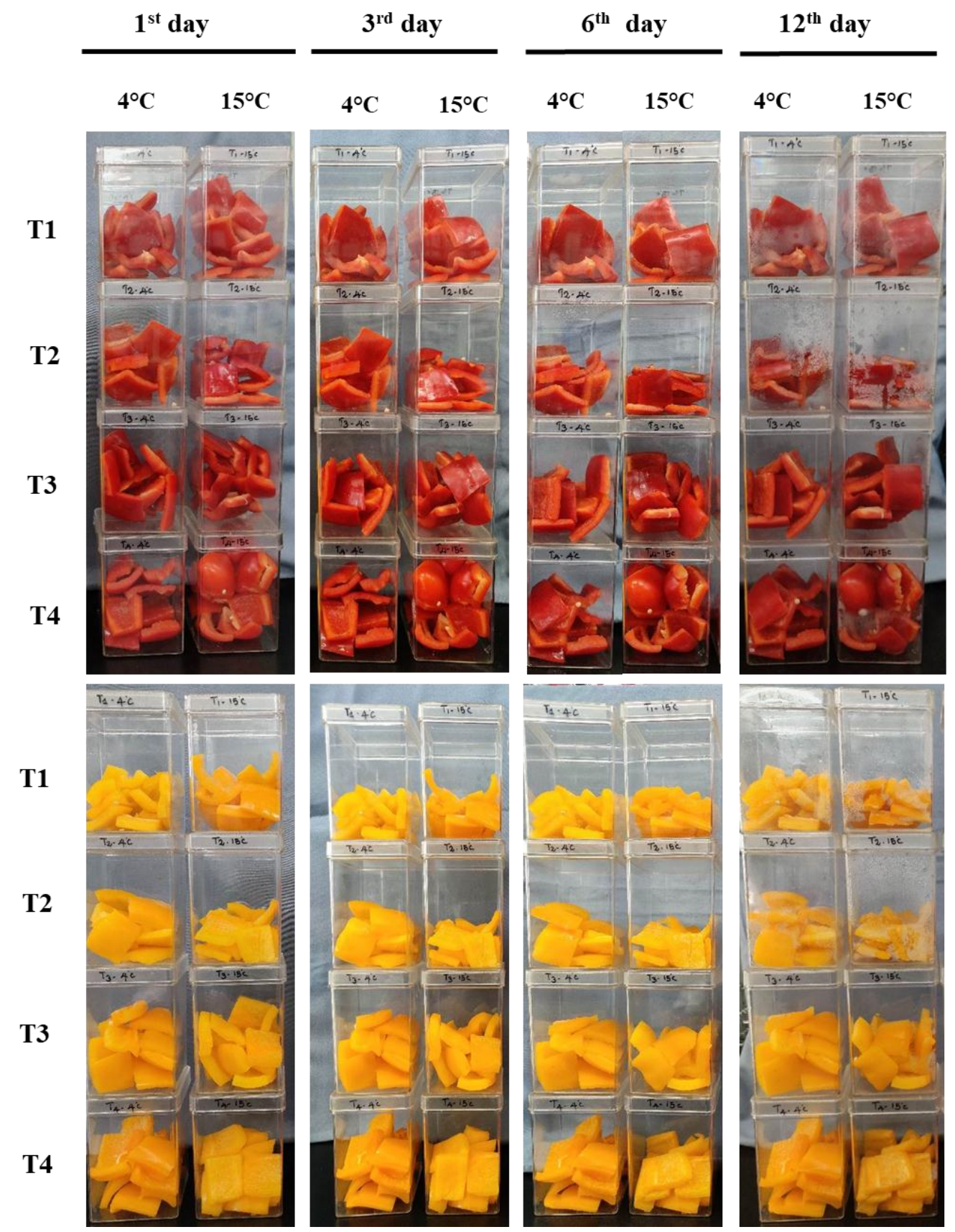

Figure 1. Effect of the Lactobacillus rhamnosus GG and biochemical additive treatments on visual appearance and sensory properties of red $(\mathrm{R})$ and yellow $(\mathrm{Y})$ fresh cut bell pepper (FCBP) in relation to day 1 , day 4 , day 6 , and day 12 intervals.

Sensory evaluation is one of the essential measures to ensure the quality of preserved fresh-cut vegetables and fruits. The present work evaluates the effect of individual and combined effects of biochemical additives and L. rhamnosus GG treatments on FCBP stored at two different temperatures for 15 days. FCBP was testable for up to 12 days, but later it was deteriorated through colonization of microbial and foodborne contaminants. Therefore, the biochemical additive and L. rhamnosus GG-treated FCBP stored at $4{ }^{\circ} \mathrm{C}$ and $15^{\circ} \mathrm{C}$ after the 12 th day were subjected to the sensory evaluation using an expert panel. The quality of FCBP was very poor when stored at $15^{\circ} \mathrm{C}$ for 12 days, while the $4{ }^{\circ} \mathrm{C}$ storage showed promising sensory quality with limited commercialization (Figure 2a,b). The treatment of the additive solution did not show the significance at the fourth day interval, but later it prevented the colonization of the foodborne pathogens and maintained the quality for up to 8 days 
(T1). Inoculation with FBC and a biochemical additive solution (T2) was not effective at $15^{\circ} \mathrm{C}$ for the storage of FCBP. However, the combined inoculation of the biochemical additives and L. rhamnosus GG treatments (T4 and T3) maintained the quality of red and yellow FCBP for up to 12 days at $4{ }^{\circ} \mathrm{C}$ of storage temperature without loss of nutritional values (Figure 2a,b).

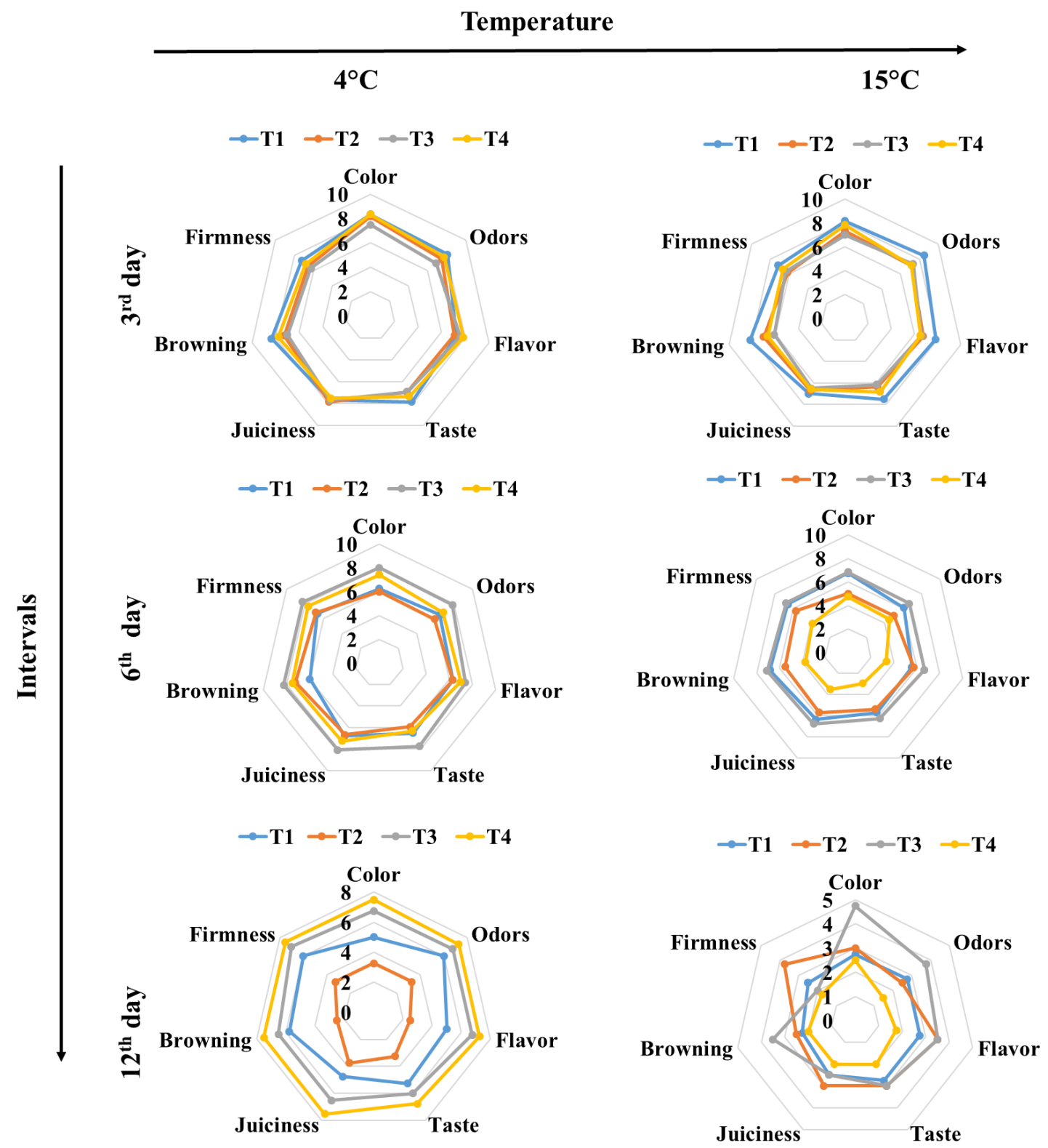

(a)

Figure 2. Cont. 


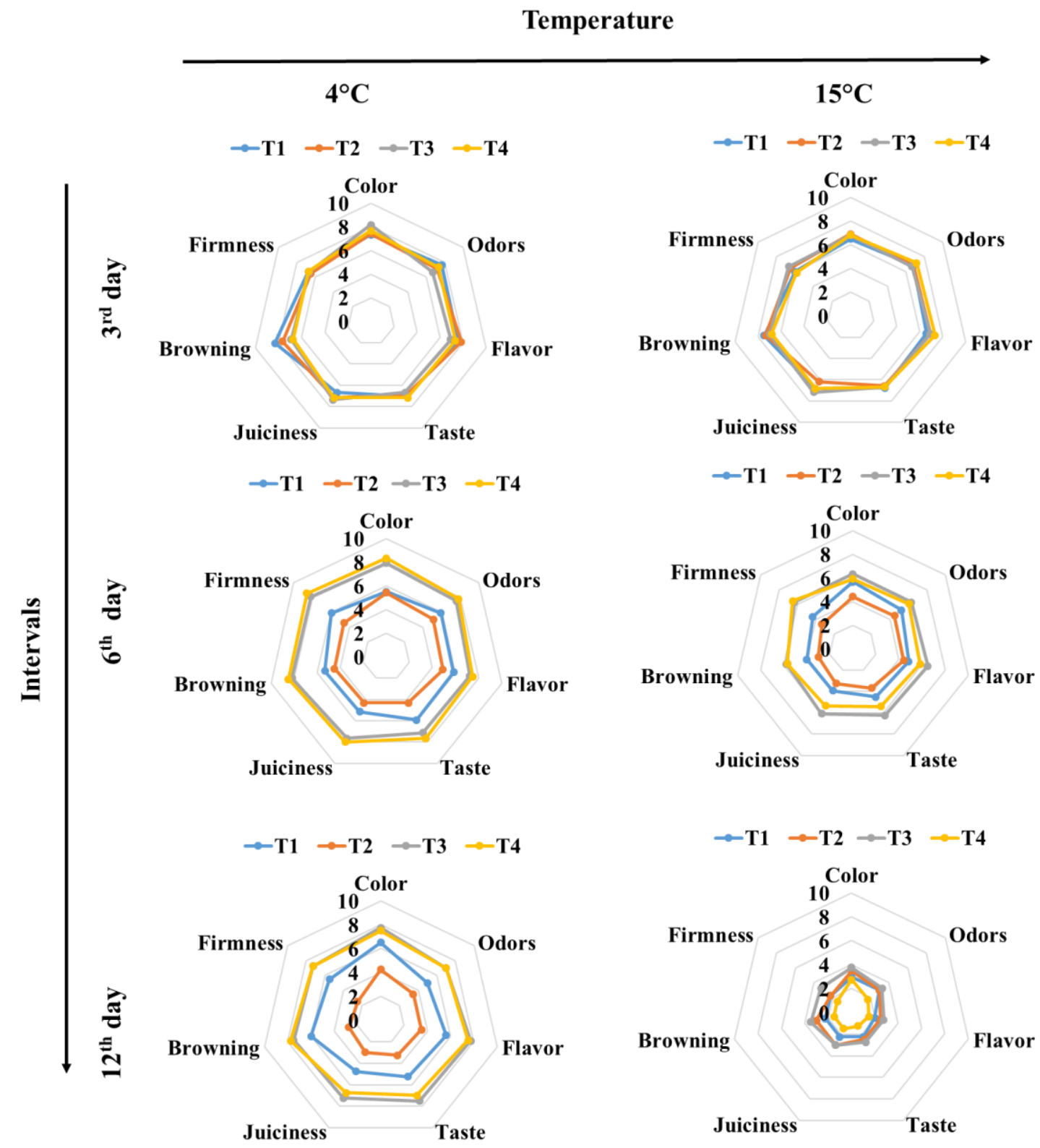

(b)

Figure 2. (a) Effect of the Lactobacillus rhamnosus GG and biochemical additives treatments on the sensory properties of red (R) fresh-cut bell pepper (FCBP) in comparison to day 4, day 6, and day 12 intervals. (b) Effect of the Lactobacillus rhamnosus GG and biochemical agent's treatments on the sensory properties of yellow (Y) fresh cut bell pepper (FCBP) in comparison to day 4, day 6, and day 12 intervals.

\section{Conclusions}

This work assessed the combined and individual effects of biochemical additives and L. rhamnosus GG treatments on the preservation of FCBP at two different temperatures for 15 days. The results revealed that the application of the biochemical additive alone was effective until 8 days of the storage at $4{ }^{\circ} \mathrm{C}$, while the combined treatment (T4) and L. rhamnosus GG alone (T3) treatments maintained the quality of the FCBP for 12 days at $4{ }^{\circ} \mathrm{C}$ with potential antioxidant properties by preventing the colonization of foodborne pathogens. Thus, the application of the probiotic strain improves the shelf life and quality of FCBP. 
Supplementary Materials: The following are available online at http://www.mdpi.com/2304-8158/9/9/1252/s1, Table S1: Microbial counts, such as total bacterial counts (TBC), total fungal count (TFC), total Salmonella sp. count (TSC), and total Listeria sp. count (TLC), of red fresh-cut bell pepper (R-FCBP) processed with different treatments and preserved at $4{ }^{\circ} \mathrm{C}$ and $15{ }^{\circ} \mathrm{C}$. The results were presented as mean $\pm \mathrm{SE}\left(n^{-3}\right)$. Table S2: Determination of microbial counts of total bacterial (TBC), total fungi (TFC), total Salmonella sp. (TSC), and total Listeria sp. (TLC) from yellow fresh-cut bell pepper (Y-FCBP) processed with different treatments and preserved at $4{ }^{\circ} \mathrm{C}$ and $15^{\circ} \mathrm{C}$. The results were presented as mean $\pm \mathrm{SE}\left(n^{-3}\right)$.

Author Contributions: Conceptualization, data curation, formal analysis, investigation, methodology, visualization, roles/writing_original draft, and writing - review and editing: K.S.; data curation, formal analysis, and validation: A.S. and A.V.A.M.; methodology, data curation, and formal analysis: R.C.; software and investigation: X.H.; resources and supervision: D.H.O.; funding acquisition, project administration, resources, software, supervision, and validation: M.-H.W. All authors have read and agreed to the published version of the manuscript.

Funding: This work was supported by the Ministry of Agriculture, Food and Rural Affairs (318077-2), and one author (K.S.) received the Korea Research Fellowship Program through the National Research Foundation of Korea (NRF) funded by the Ministry of Science, ICT, and Future Planning (2017H1D3A1A01052610) Republic of Korea.

Conflicts of Interest: There is no conflict of interest in this study.

\section{References}

1. Lee, B.; Kam, D.; Min, B.; Hwa, J.; Oh, S. A vision servo system for automated harvest of sweet pepper in Korean greenhouse environment. Appl. Sci. 2019, 9, 2395. [CrossRef]

2. Choi, I.-L.; Yoo, T.J.; Kang, H.-M. UV-C treatments enhance antioxidant activity, retain quality and microbial safety of fresh-cut paprika in MA storage. Hortic. Environ. Biotechnol. 2015, 56, 324-329. [CrossRef]

3. Azarakhsh, N.; Osman, A.; Ghazali, H.M.; Tan, C.P.; Mohd Adzahan, N. Lemongrass essential oil incorporated into alginate-based edible coating for shelf-life extension and quality retention of fresh-cut pineapple. Postharv. Biol. Technol. 2014, 88, 1-7. [CrossRef]

4. Bae, Y.-M.; Choi, N.-Y.; Heu, S.; Kang, D.-H.; Lee, S.-Y. Inhibitory effects of organic acids combined with modified atmosphere packaging on foodborne pathogens on cabbage. J. Korean Soc. Appl. Biol. Chem. 2011, 54, 993-997. [CrossRef]

5. Sivapalasingam, S.; Friedman, C.R.; Cohen, L.; Tauxe, R.V. Fresh produce: A growing cause of outbreaks of foodborne illness in the United States, 1973 through 1997. J. Food Prot. 2004, 67, 2342-2353. [CrossRef]

6. European Centre for Disease Prevention and Control. Shiga Toxin-Producing E. coli (STEC): Update on Outbreak in the EU, J. Update on Outbreak in the EU. ECDC, Stockholm (2011). 2011. Available online: http://ecdc.europa.eu/en/activities/sciadvice/Lists/ECDC\%20Reviews/ECDC_DispForm.aspx? List $=512 \mathrm{ff} 74 \mathrm{f} \% 2 \mathrm{D} 77 \mathrm{~d} 4 \% 2 \mathrm{D} 4 \mathrm{ad} \%$ 2Db6d6\%2Dbf0f23083f30\&ID=1166\&RootFolder=\%2Fen \%2Factivities $\%$ 2Fsciadvice\%2FLists\%2FECDC\%20Reviews (accessed on 16 January 2012).

7. Zhu, Q.; Gooneratne, R.; Hussain, M.A. Listeria monocytogenes in Fresh Produce: Outbreaks, prevalence and contamination levels. Foods 2017, 6, 21. [CrossRef]

8. Wu, S.; Wu, Q.; Zhang, J.; Chen, M.; Yan, Z.A.; Hu, H. Listeria monocytogenes prevalence and characteristics in retail raw foods in China. PLoS ONE 2015, 10, e0136682. [CrossRef]

9. Ding, T.; Iwahori, J.I.; Kasuga, F.; Wang, J.; Forghani, F.; Park, M.-S.; Oh, D.-H. Risk assessment for Listeria monocytogenes on lettuce from farm to table in Korea. Food Control 2013, 30, 190-199. [CrossRef]

10. Oliveira, M.; Usall, J.; Solsona, C.; Alegre, I.; Viñas, I.; Abadias, M. Effects of packaging type and storage temperature on the growth of foodborne pathogens on shredded 'Romaine' lettuce. Food Microbiol. 2010, 27, 375-380. [CrossRef]

11. Luo, Y.; He, Q.; McEvoy, J.L. Effect of storage temperature and duration on the behavior of Escherichia coli O157:H7 on packaged fresh-cut salad containing romaine and iceberg lettuce. J. Food Sci. 2010, 75, M390-M397. [CrossRef]

12. Alegre, I.; Abadias, M.; Anguera, M.; Oliveira, M.; Viñas, I. Factors affecting growth of foodborne pathogens on minimally processed apples. Food Microbiol. 2010, 27, 70-76. [CrossRef] [PubMed]

13. Leverentz, B.; Conway, W.S.; Alavidze, Z.; Janisiewicz, W.J.; Fuchs, Y.; Camp, M.J.; Chighladze, E.; Sulakvelidze, A. Examination of bacteriophage as a biocontrol method for Salmonella on fresh-cut fruit: A model study. J. Food Prot. 2001, 64, 1116-1121. [CrossRef] [PubMed] 
14. Alegre, I.; Abadias, M.; Anguera, M.; Usall, J.; Viñas, I. Fate of Escherichia coli O157:H7, Salmonella and Listeria innocua on minimally-processed peaches under different storage conditions. Food Microbiol. 2010, 27, 862-868. [CrossRef]

15. Seo, Y.-H.; Jang, J.-H.; Moon, K.-D. Microbial evaluation of minimally processed vegetables and sprouts produced in Seoul, Korea. Food Sci. Biotechnol. 2010, 19, 1283-1288. [CrossRef]

16. Lynch, M.F.; Tauxe, R.V.; Hedberg, C.W. The growing burden of foodborne outbreaks due to contaminated fresh produce: Risks and opportunities. Epidemiol. Infect. 2009, 137, 307-315. [CrossRef] [PubMed]

17. Oliveira, M.; Abadias, M.; Colás-Medà, P.; Usall, J.; Viñas, I. Biopreservative methods to control the growth of foodborne pathogens on fresh-cut lettuce. Int. J. Food Microbiol. 2015, 214, 4-11. [CrossRef]

18. Rojas-Graü, M.A.; Soliva-Fortuny, R.; Martín-Belloso, O. Edible coatings to incorporate active ingredients to fresh-cut fruits: A review. Trends Food Sci. Technol. 2009, 20, 438-447. [CrossRef]

19. Bico, S.L.S.; Raposo, M.F.J.; Morais, R.M.S.C.; Morais, A.M.M.B. Combined effects of chemical dip and/or carrageenan coating and/or controlled atmosphere on quality of fresh-cut banana. Food Control 2009, 20, 508-514. [CrossRef]

20. Gorny, J.R.; Hess-Pierce, B.; Cifuentes, R.A.; Kader, A.A. Quality changes in fresh-cut pear slices as affected by controlled atmospheres and chemical preservatives. Postharv. Biol. Technol. 2002, 24, 271-278. [CrossRef]

21. Peng, M.; Reichmann, G.; Biswas, D. Lactobacillus casei and its byproducts alter the virulence factors of foodborne bacterial pathogens. J. Func. Foods 2015, 15, 418-428. [CrossRef]

22. Iglesias, M.B.; Echeverría, G.; Viñas, I.; López, M.L.; Abadias, M. Biopreservation of fresh-cut pear using Lactobacillus rhamnosus GG and effect on quality and volatile compounds. LWT 2018, 87, 581-588. [CrossRef]

23. Siroli, L.; Patrignani, F.; Serrazanetti, D.I.; Tabanelli, G.; Montanari, C.; Gardini, F.; Lanciotti, R. Lactic acid bacteria and natural antimicrobials to improve the safety and shelf-life of minimally processed sliced apples and lamb's lettuce. Food Microbiol. 2015, 47, 74-84. [CrossRef] [PubMed]

24. Siroli, L.; Patrignani, F.; Serrazanetti, D.I.; Tappi, S.; Rocculi, P.; Gardini, F.; Lanciotti, R. Natural antimicrobials to prolong the shelf-life of minimally processed lamb's lettuce. Postharv. Biol. Technol. 2015, 103, 35-44. [CrossRef]

25. Alegre, I.; Viñas, I.; Usall, J.; Anguera, M.; Abadias, M. Microbiological and physicochemical quality of fresh-cut apple enriched with the probiotic strain Lactobacillus rhamnosus GG. Food Microbiol. 2011, 28, 59-66. [CrossRef]

26. Iglesias, M.B.; Abadias, M.; Anguera, M.; Sabata, J.; Viñas, I. Antagonistic effect of probiotic bacteria against foodborne pathogens on fresh-cut pear. LWT Food Sci. Technol. 2017, 81, 243-249. [CrossRef]

27. Aslam, M.; Khalid, S.; Kamran, H.; Azhar, S.; Hamid, S. Determination of sodium benzoate in selected samples of fruit juices and squashes. AJAHS 2017, 2, 26-31.

28. Saravanakumar, K.; Hu, X.; Chelliah, R.; Oh, D.-H.; Kathiresan, K.; Wang, M.-H. Biogenic silver nanoparticles-polyvinylpyrrolidone based glycerosomes coating to expand the shelf life of fresh-cut bell pepper (Capsicum annuum L. var. grossum (L.) Sendt). Postharv. Biol. Technol. 2020, 160, 111039. [CrossRef]

29. Singleton, V.L.; Rossi, J.A. Colorimetry of total phenolics with phosphomolybdic-phosphotungstic acid reagents. Am. J. Enol. Vitic. 1965, 16, 144-158.

30. Ardestani, A.; Yazdanparast, R. Inhibitory effects of ethyl acetate extract of Teucrium polium on in vitro protein glycoxidation. Food Chem. Toxicol. 2007, 45, 2402-2411. [CrossRef]

31. Russo, P.; Peña, N.; de Chiara, M.L.V.; Amodio, M.L.; Colelli, G.; Spano, G. Probiotic lactic acid bacteria for the production of multifunctional fresh-cut cantaloupe. Food Res. Int. 2015, 77, 762-772. [CrossRef]

32. Cross, M.L. Immunoregulation by probiotic lactobacilli: Pro-Th1 signals and their relevance to human health. Clin. Appl. Immunol. Rev. 2002, 3, 115-125. [CrossRef]

33. McCann, M.J.; Gill, C.I.R.; O’ Brien, G.; Rao, J.R.; McRoberts, W.C.; Hughes, P.; McEntee, R.; Rowland, I.R. Anti-cancer properties of phenolics from apple waste on colon carcinogenesis in vitro. Food Chem. Toxicol. 2007, 45, 1224-1230. [CrossRef] [PubMed]

34. Nguyen, T.D.T.; Kang, J.H.; Lee, M.S. Characterization of Lactobacillus plantarum PH04, a potential probiotic bacterium with cholesterol-lowering effects. Int. J. Food Microbiol. 2007, 113, 358-361. [CrossRef]

35. Reid, G.; Burton, J. Use of Lactobacillus to prevent infection by pathogenic bacteria. Microbes Infect. 2002, 4, 319-324. [CrossRef]

36. Lee, H.Y.; Xu, H.; Lee, H.J.; Lim, T.I.; Choi, Y.B.; Ko, J.R.; Ahn, J.; Mustapha, A. Prophylactic uses of probiotics as a potential alternative to antimicrobials in food animals. Food Sci. Biotechnol. 2008, 17, 191-194. 
37. Karami, S.; Roayaei, M.; Zahedi, E.; Bahmani, M.; Mahmoodnia, L.; Hamzavi, H.; Rafieian-Kopaei, M. Antifungal effects of Lactobacillus species isolated from local dairy products. Int. J. Pharm. Investig. 2017, 7, 77-81. [CrossRef] [PubMed]

38. Cabo, M.L.; Braber, A.F.; Koenraad, P.M. Apparent antifungal activity of several lactic acid bacteria against Penicillium discolor is due to acetic acid in the medium. J. Food Prot. 2002, 65, 1309-1316. [CrossRef]

39. Lennerz, B.S.; Vafai, S.B.; Delaney, N.F.; Clish, C.B.; Deik, A.A.; Pierce, K.A.; Ludwig, D.S.; Mootha, V.K. Effects of sodium benzoate, a widely used food preservative, on glucose homeostasis and metabolic profiles in humans. Mol. Genet. Metab. 2015, 114, 73-79. [CrossRef]

40. Rojas-Graü, M.A.; Sobrino-López, A.; Soledad Tapia, M.; Martín-Belloso, O. Browning inhibition in fresh-cut 'Fuji' apple slices by natural antibrowning agents. J. Food Sci. 2006, 71, S59-S65. [CrossRef]

41. Zambrano-Zaragoza, M.L.; Mercado-Silva, E.; Del Real, L.A.; Gutiérrez-Cortez, E.; Cornejo-Villegas, M.A.; Quintanar-Guerrero, D. The effect of nano-coatings with $\alpha$-tocopherol and xanthan gum on shelf-life and browning index of fresh-cut "red Delicious" apples. Innov. Food Sci. Emerg. Technol. 2014, 22, 188-196. [CrossRef]

42. Koushesh Saba, M.; Sogvar, O.B. Combination of carboxymethyl cellulose-based coatings with calcium and ascorbic acid impacts in browning and quality of fresh-cut apples. LWT Food Sci. Technol. 2016, 66, 165-171. [CrossRef]

43. Martínez-Romero, D.; Castillo, S.; Guillén, F.; Díaz-Mula, H.M.; Zapata, P.J.; Valero, D.; Serrano, M. Aloe vera gel coating maintains quality and safety of ready-to-eat pomegranate arils. Postharv. Biol. Technol. 2013, 86, 107-112. [CrossRef]

44. Saxena, A.; Saxena, T.M.; Raju, P.S.; Bawa, A.S. Effect of controlled atmosphere storage and chitosan coating on quality of fresh-cut jackfruit bulbs. Food Bioproc. Technol. 2013, 6, 2182-2189. [CrossRef]

45. Russo, P.; de Chiara, M.L.V.; Vernile, A.; Amodio, M.L.; Arena, M.P.; Capozzi, V.; Massa, S.; Spano, G. Fresh-Cut Pineapple as a New Carrier of Probiotic Lactic Acid Bacteria. BioMed Res. Int. 2014, 2014, 309183. [CrossRef]

(C) 2020 by the authors. Licensee MDPI, Basel, Switzerland. This article is an open access article distributed under the terms and conditions of the Creative Commons Attribution (CC BY) license (http://creativecommons.org/licenses/by/4.0/). 